\title{
Endothelial Activation Markers in Anemic Non-Dialysis Chronic Kidney Disease Patients
}

\author{
Tejas V. Patel Bharati V. Mittal Sai Ram Keithi-Reddy Jeremy S. Duffield \\ Ajay K. Singh
}

Renal Division, Brigham and Women's Hospital, and Harvard Medical School, Boston, Mass., USA

\section{Key Words}

Anemia - Chronic kidney disease • Endothelial markers • Fibrinogen • Vascular cell adhesion molecule-1 • Von Willebrand factor

\begin{abstract}
Background/Aims: Anemia in chronic kidney disease is an independent predictor of cardiovascular disease (CVD). We explored the relationship between anemia and markers of inflammation and endothelial activation in non-dialysis chronic kidney disease (ND-CKD) patients to understand this mechanism. Methods: Cross-sectional analysis was performed on 30 adult ND-CKD patients for markers of inflammation and endothelial activation using a multiplexed immunoassay. Data were analyzed according to the anemic status defined by the modified World Health Organization criteria. Results: Seventeen patients were classified as anemic. Baseline characteristics by anemic status were similar except that anemic patients were older $(p=0.006)$, had lower estimated glomerular filtration rate (eGFR; $p=0.01)$ and higher prevalence of CVD ( $p=0.02)$. Compared to non-anemic patients, log-transformed values of fibrinogen ( $p=$ 0.012); von Willebrand factor ( $v W F, p=0.008)$, vascular cell adhesion molecule-1 (VCAM-1, $\mathrm{p}=0.025$ ) and C-reactive protein ( $p=0.043$ ) were elevated in anemic patients. Serum ferritin ( $p=0.93$ ) and serum albumin ( $p=0.06)$ were not different. Age and eGFR-adjusted logistic regression anal-
\end{abstract}

ysis showed that anemic patients had increased odds for a composite of higher median values of fibrinogen, vWF and VCAM-1 ( $p=0.01$, odds ratio $8.1,95 \% \mathrm{Cl} 1.08-111.0$ ). Conclusion: We report the association of anemia with elevated markers of endothelial activation in ND-CKD patients. Longitudinal studies are needed to confirm our findings.

Copyright ๑ 2008 S. Karger AG, Basel

\section{Introduction}

In chronic kidney disease, the overall cardiovascular disease (CVD) mortality rate is up to 30 -fold higher than the age-adjusted CVD mortality in the general population [1]. Traditional biomarkers appear insufficient to predict CVD risk and novel non-traditional biomarkers are being scrutinized to better predict adverse CVD events [2-6]. These novel markers are detectable even among patients without evidence of abnormalities in traditional biomarkers $[6,7]$. Anemia is a common complication among patients with chronic kidney disease (CKD) [8], and is an independent risk factor for adverse cardiovascular outcome in CKD [9-12]. However, the mechanism remains unclear. Identifying mechanisms beyond the traditional risk factors may help to better explain CVD in anemic non-dialysis CKD (ND-CKD) and endstage renal disease patients.

\section{KARGER}

Fax +4161306 1234 E-Mail karger@karger.ch www.karger.com
(C) 2008 S. Karger AG, Basel

$1660-2110 / 08 / 1104-0244 \$ 24.50 / 0$

Accessible online at:

www.karger.com/nec
Ajay K. Singh

Renal Division, Brigham and Women's Hospita

MRB-4, 75 Francis St, Boston, MA 02115 (USA)

Tel. +1 617732 5951, Fax +1 6177326392

E-Mail asingh@partners.org 
Markers of inflammation have received attention as predictors of CVD outcome in the general population and patients with CKD [2, 13-15]. However, markers of endothelial activation have not been explored in anemic ND-CKD patients. We sought to explore the relationship between biomarkers of endothelial activation and inflammation and anemia in ND-CKD patients. We analyzed ferritin, albumin, C-reactive protein (CRP), fibrinogen, von Willebrand factor (vWF) and vascular adhesion molecule-1 (VCAM-1). These markers have been associated with increased mortality in different population groups [6, 16-18]. In addition to being previously validated, they are all available in commercial assays allowing replication of our study.

\section{Materials and Methods}

We utilized data from a prospective observational ND-CKD cohort that we established in 2004 at the Brigham and Women's Hospital. This cohort is designed to study the influence of specific modifiable factors on the risk of progression of CKD and the risk of CVD in patients with CKD. For inclusion in the cohort, subjects were required to be aged $>18$ years and have CKD as defined by Levey et al. [19]. The estimated glomerular filtration rate (eGFR) was calculated by the Modification of Diet in Renal Disease (MDRD) II equation (eGFR [ml/min per $\left.1.73 \mathrm{~m}^{2}\right]$ $=186 \times[\mathrm{Cr}(\mathrm{mg} / \mathrm{dl})]^{-1.154} \times[\text { age }]^{-0.203} \times[1.21$ if the subject is black $] \times[0.74$ if the subject is a female $])$. Exclusion criteria included: unwillingness to provide informed consent; patients who were hospitalized or had a thrombotic or CVD event 1 month prior to enrollment; institutionalized subjects; those with a life expectancy of $<6$ months; known HIV patients; patients with an active malignant neoplastic disease other than localized non-melanoma skin cancer; patients on immunosuppressive treatment; patients with multiple myeloma; patients enrolled in an intervention study, and patients on dialysis. The institutional review board approved the study and informed consent was obtained from each patient. Anemia was defined by the modified World Health Organization (WHO) criteria: Hgb $<120 \mathrm{~g} / \mathrm{l}$ in women, $\mathrm{Hgb}<130 \mathrm{~g} / \mathrm{l}$ in men or treatment with epoetin. Treatment with epoetin and the dose utilized was ascertained by review of the medical records, direct contact with the patient, and reviewing the pharmacy record. Iron deficiency was defined by a total iron-binding capacity (TSAT) of $<15 \%$ or serum ferritin of $<100 \mathrm{pmol} / \mathrm{l}$.

\section{Analysis of the Serum Specimens}

Blood was collected from 30 patients after overnight fasting using venipuncture and collection tubes from Becton-Dickinson. Samples were aliquotted and frozen at $-80^{\circ} \mathrm{C}$. The samples were shipped on dry ice to Rules-Based Medicine, Inc. (Austin, Tex., USA) for tests. Markers of inflammation and endothelial activation were analyzed by Luminex with internal controls: CRP, albumin, ferritin, fibrinogen, vWF, and VCAM-1.
Statistical Analysis

Baseline data were analyzed using the following statistical methods: continuous data were analyzed with an independent sample non-parametric test and categorical data were analyzed with Fisher's exact test in the analysis of demographic characteristics. Biomarkers that reached significance were further analyzed. The levels of serum ferritin, albumin, CRP, fibrinogen, vWF, and VCAM-1 levels deviated from the normal distribution and log-transformation reduced skew deviation. We used the Mann-Whitney U test to compare anemic and non-anemic patients. Spearman correlation coefficients were calculated for pairs of continuous variables. Logistic regression was used to calculate the odds ratio for reaching a composite end point of a higher median of fibrinogen, vWF and VCAM-1. SPSS version 15 (SPSS Inc., Chicago, Ill., USA) was used to analyze the data.

\section{Results}

Patient Characteristics by CKD-Associated Anemia

The baseline characteristics of the subjects are presented in table 1 . Anemia was defined by the modified WHO criteria as $<120 \mathrm{~g} / \mathrm{l}$ in women and $<130 \mathrm{~g} / \mathrm{l}$ in men or treatment with epoetin. Of the 30 patients analyzed, 17 patients were anemic by the modified WHO criteria. As expected, the mean Hgb level differed significantly among the groups $(106 \pm 16$ vs. $138 \pm 12 \mathrm{~g} / \mathrm{l}, \mathrm{p}<0.001$, anemic vs. non-anemic). Anemic patients were older $(68.18 \pm 14.17$ vs. $49.23 \pm 20.83$ years, $\mathrm{p}=0.006$, anemic vs. non-anemic). Serum creatinine was not different between the groups $(274.04 \pm 97.24$ vs. $212.16 \pm 132.6$ $\mu \mathrm{mol} / \mathrm{l}, \mathrm{p}=0.13$, anemic vs. non-anemic); however, the eGFR reached statistical significance $(22.4 \pm 13.5$ vs. $47.0 \pm 35.0 \mathrm{ml} / \mathrm{min}, \mathrm{p}=0.01$, anemic vs. non-anemic). Of note, anemic patients had a higher prevalence of CVD ( $\mathrm{p}=0.02)$. Serum ferritin, low-density lipoprotein, smoking status, presence of proteinuria, serum albumin, complement C3, and parathyroid hormone were not significantly different between the 2 groups. Erythropoiesis-stimulating agents (ESAs) were prescribed in 8 anemic patients at a mean dose of $85 \pm 42$ units $/ \mathrm{kg} /$ week.

\section{Biomarkers by Anemic Status}

In this study, we focused on endothelial markers. The levels of ferritin, albumin, CRP, fibrinogen, vWF and VCAM-1 were examined with respect to anemic status. Since the markers were not normally distributed, values were log-transformed. Non-parametric test showed elevated levels of log-transformed CRP in patients with anemia and reached significance $(p=0.043)$. However, log- 
Table 1. Baseline characteristics of CKD patients by anemia status ${ }^{1}$

\begin{tabular}{|c|c|c|c|}
\hline Characteristic & $\begin{array}{l}\text { Anemic CKD } \\
(\mathrm{n}=17)\end{array}$ & $\begin{array}{l}\text { Non-anemic CKD } \\
(\mathrm{n}=13)\end{array}$ & $\begin{array}{l}\mathrm{p} \\
\text { value }^{2}\end{array}$ \\
\hline Age, years & $68.18 \pm 14.17$ & $49.23 \pm 20.83$ & 0.006 \\
\hline Female gender & $10(58 \%)$ & $5(38 \%)$ & 0.28 \\
\hline Race & & & 0.46 \\
\hline Caucasian & $7(41 \%)$ & $5(53 \%)$ & \\
\hline African American & $8(53 \%)$ & $3(23 \%)$ & \\
\hline Hispanic & $1(5 \%)$ & $2(15 \%)$ & \\
\hline Others & $1(5 \%)$ & $1(7 \%)$ & \\
\hline Etiology of chronic kidney disease & & & 0.69 \\
\hline Diabetic nephropathy & $6(35 \%)$ & $3(23 \%)$ & \\
\hline Non-diabetic & $11(64 \%)$ & $10(76 \%)$ & \\
\hline Hypertension & $8(47 \%)$ & $2(15 \%)$ & \\
\hline Chronic glomerulonephritis & $2(11 \%)$ & $6(53 \%)$ & \\
\hline Others & $1(5 \%)$ & $1(5 \%)$ & \\
\hline PTH, ng/l & $240 \pm 183.7$ & $146.4 \pm 127.5$ & 0.14 \\
\hline Serum creatinine, $\mu \mathrm{mol} / \mathrm{l}$ & $274.04 \pm 97.24$ & $212.16 \pm 132.6$ & 0.13 \\
\hline MDRD GFR, $\mathrm{ml} / \mathrm{min} / 1.73 \mathrm{~m}^{2}$ & $22.4 \pm 13.5$ & $47.0 \pm 35.0$ & 0.01 \\
\hline Hemoglobin, g/l & $106 \pm 16$ & $138 \pm 12$ & $<0.001$ \\
\hline Transferrin saturation, $\%$ & $22 \pm 15$ & $29 \pm 15$ & 0.11 \\
\hline Ferritin, pmol/l & $544.89 \pm 865.3$ & $321.3 \pm 173$ & 0.26 \\
\hline Low-density lipoprotein cholesterol, mmol/l & $2.58 \pm 1.3$ & $2.85 \pm 1.1$ & 0.65 \\
\hline Proteinuria of $>300 \mathrm{mg} / \mathrm{g}$ present, $\mathrm{n}$ & $11(64 \%)$ & $5(38 \%)$ & 0.28 \\
\hline Proteinuria, $\mathrm{mg} / \mathrm{g}$ & $987.5 \pm 810.6$ & $447.9 \pm 689$ & 0.08 \\
\hline Albumin, g/l & $41 \pm 3.0$ & $43 \pm 3.0$ & 0.1 \\
\hline Smoking, $\mathrm{n}$ & 3 & 2 & 0.36 \\
\hline Complement 3, g/l & $0.76 \pm 0.15$ & $0.74 \pm 0.19$ & 0.63 \\
\hline Coronary artery disease, $\mathrm{n}$ & 6 & 2 & 0.02 \\
\hline Congestive heart failure, $\mathrm{n}$ & 4 & 2 & 0.27 \\
\hline Blood group A-positive, $\mathrm{n}$ & 3 & 4 & 0.23 \\
\hline
\end{tabular}

\footnotetext{
All continuous data are expressed as mean \pm SD and categorical data are expressed in percentages.

${ }^{1}$ The modified WHO classification of anemia is used where anemia is defined as the presence of $\mathrm{Hgb}<120$ $\mathrm{g} / \mathrm{l}$ in women or $\mathrm{Hgb}<130 \mathrm{~g} / \mathrm{l}$ in men or treatment with erythropoiesis-stimulating agents.

${ }^{2}$ Significant if $\mathrm{p}$ value is $<0.05$.
}

transformed levels of serum albumin $(\mathrm{p}=0.06)$ and serum ferritin $(\mathrm{p}=0.93)$ were not different in anemic and non-anemic CKD patients. Log-transformed values of the markers of endothelial activation were significantly elevated in the anemic patients: fibrinogen $(\mathrm{p}=0.012)$, $\operatorname{vWF}(\mathrm{p}=0.008)$, and VCAM1 $(\mathrm{p}=0.025)$.

\section{Sensitivity Analysis}

Analysis of Biomarkers by Various Anemia

Definitions

We performed sensitivity analyses using different classifications of anemia to evaluate the robustness of the associations between various biomarkers and anemia status (table 2). The first sensitivity analysis strictly clas- sified patients based on the WHO criteria regardless of epoetin treatment as a cause of anemia (WHO definition of anemia is $<130 \mathrm{~g} / \mathrm{l}$ for adult males and $<120 \mathrm{~g} / \mathrm{l}$ an adult females): 16 patients were classified as anemic. Log CRP $(p=0.06)$ was higher in the anemic patients but did not reach significance. Log albumin was lower in anemic patients $(\mathrm{p}=0.03)$. In contrast, markers of endothelial activation were significantly elevated in anemic patients: log fibrinogen $(\mathrm{p}=0.025), \log \mathrm{vWF}(\mathrm{p}=0.004)$, and $\log$ VCAM-1 ( $p=0.042)$. Log serum ferritin was not significant between the groups $(\mathrm{p}=0.82)$. A second sensitivity analysis was performed based on the National Kidney Foundation (NKF) criteria for anemia (anemia is $<135$ $\mathrm{g} / \mathrm{l}$ for an adult male and $<120 \mathrm{~g} / \mathrm{l}$ for an adult female): 19 
Table 2. Sensitivity analysis of inflammatory and endothelial markers by anemia status in non-dialysis CKD patients

\begin{tabular}{llll}
\hline Marker & \multicolumn{2}{l}{ p value by } & \\
\cline { 2 - 4 } & $\begin{array}{l}\text { NKF } \\
\text { criteria } \\
\text { anemic } \\
(\mathrm{n}=19)\end{array}$ & $\begin{array}{l}\text { Modified } \\
\text { WHO criteria } \\
\text { anemic } \\
(\mathrm{n}=17)\end{array}$ & $\begin{array}{l}\text { WHO } \\
\text { criteria } \\
\text { anemic } \\
(\mathrm{n}=16)\end{array}$ \\
\hline CRP & 0.023 & 0.043 & 0.06 \\
Ferritin & 0.611 & 0.93 & 0.82 \\
Serum albumin & 0.03 & 0.06 & 0.031 \\
VCAM-1 & 0.005 & 0.025 & 0.042 \\
Von Willebrand factor & 0.006 & 0.008 & 0.004 \\
Fibrinogen & 0.005 & 0.012 & 0.025 \\
\hline
\end{tabular}

Mann-Whitney $\mathrm{U}$ test was performed for analysis with logtransformed values as dependent variables.

patients were classified as anemic. The log CRP was significantly higher $(\mathrm{p}=0.02)$ and serum albumin was significantly lower $(\mathrm{p}=0.03)$ in anemic patients compared to the non-anemic patients. Serum ferritin levels were again not significant $(\mathrm{p}=0.61)$. The endothelial markers were again significantly elevated: $\log$ fibrinogen $(\mathrm{p}=$ 0.005), $\log \mathrm{vWF}(\mathrm{p}=0.006)$ and $\log$ VCAM-1 ( $\mathrm{p}=0.005)$. Eight subjects were receiving ESAs. These markers did not differ significantly by ESA status among the anemic subjects (i.e., anemic subjects exposed to ESA vs. anemic subjects not exposed to ESA). Serum fibrinogen (4.9 $\mu \mathrm{mol} / \mathrm{l}$ in anemic patients on ESA vs. $5.2 \mu \mathrm{mol} / \mathrm{l}$ in anemic patients not on ESA, $\mathrm{p}=0.77)$, VCAM-1 $(647 \mathrm{ng} / \mathrm{l}$ in anemic patients on ESA vs. $717 \mathrm{ng} / \mathrm{l}$ in anemic patients not on ESA, $\mathrm{p}=0.33)$ and $\mathrm{vWF}(70.12 \mathrm{ng} / \mathrm{ml}$ in anemic patients on ESA vs. $70.33 \mathrm{ng} / \mathrm{ml}$ in anemic patients not on ESA, $p=0.98$ ). Two subjects in each group met the criteria for iron deficiency. Two subjects in the anemic and 1 in the non-anemic group were receiving oral iron. None of the patients were on intravenous iron treatment.

\section{Correlation between Markers of Endothelial}

Activation

A positive Spearman rank correlation was noted among the markers of endothelial activation: $\log$ fibrinogen levels positively correlated with log vWF levels $(r=$ 0.767; $\mathrm{p}<0.001)$; log fibrinogen and log VCAM-1 ( $\mathrm{r}=$ $0.26 ; \mathrm{p}=0.023)$, and $\log$ VCAM-1 and $\log \mathrm{vWF}(\mathrm{r}=0.42$, $\mathrm{p}=0.019)$. We analyzed the correlation by using median levels: there was a significant correlation between VCAM1 and fibrinogen levels $(r=0.40, p=0.023)$, VCAM- 1 and
vWF $(r=0.21, p=0.03)$, and vWF and fibrinogen levels $(\mathrm{r}=0.46, \mathrm{p}=0.009)$.

\section{Analysis of Anemia Status by Median Values of Biomarkers}

In addition to the analysis of log-transformed values of the biomarkers, different cutoff values were used to further analyze the association of these biomarkers with anemic status as defined by the modified WHO criteria. Data were analyzed by median values as cutoff. CRP (median $2.5 \mathrm{~g} / \mathrm{l}, \mathrm{p}=0.15)$, ferritin (308.9 pmol/l, $\mathrm{p}=1.0)$ and albumin (42 g/l, p = 0.07) were not significantly different between anemic and non-anemic patients. However, serum fibrinogen (median $12.9 \mu \mathrm{mol} / \mathrm{l}, \mathrm{p}=0.02, \mathrm{r}=0.47$ ), vWF (median $56 \mathrm{ng} / \mathrm{ml}, \mathrm{p}=0.02, \mathrm{r}=0.47$ ) and VCAM-1 (median $615.5 \mathrm{ng} / \mathrm{l}, \mathrm{p}=0.02, \mathrm{r}=0.39$ ) were significantly elevated in anemic compared to non-anemic patients. Median eGFR ( $23 \mathrm{ml} / \mathrm{min})$ approached statistical significance with respect to anemia by the modified WHO criteria $(p=0.07)$. Anemia was analyzed by median age of 65 years. Age influenced the anemic status of significantly $(\mathrm{p}=0.025)$. A multivariate model was constructed with a composite of medians of the three-endothelial markers and median age and median eGFR. After adjusting for age and eGFR, the composite endpoint of reaching higher median values of VCAM-1, vWF and fibrinogen was significant in anemic compared to non-anemic patients $(\mathrm{p}=0.01$, OR 8.1, 95\% CI 1.08-111.0, $\mathrm{r}=0.61)$.

\section{Endothelial Markers by Renal Function and Age}

The interaction of serum fibrinogen, vWF and VCAM1 with age and renal function was analyzed. Log serum fibrinogen $(p=0.10)$, log vWF $(p=0.08)$ and log VCAM$1(\mathrm{p}=0.06)$ showed a trend for statistical significance. Renal function by eGFR showed that patients with lower eGFR had higher VCAM-1 $(\mathrm{p}=0.06)$ and higher vWF $(\mathrm{p}=0.07)$, but this did not reach significance. Serum log fibrinogen was significantly elevated $(p=0.04)$ by renal function status.

\section{Discussion}

In this study our main finding was an association of higher fibrinogen, vWF and VCAM-1 with anemia in ND-CKD patients. Log-transformed values of CRP, fibrinogen, vWF and VCAM-1 were significantly elevated in anemic compared to non-anemic CKD patients. Serum albumin was significantly lower in anemic CKD patients. In a multivariate analysis model, median fibrino- 
gen, vWF and VCAM-1 were significantly elevated in anemic CKD patients. Sensitivity analyses using different cutoff values for anemia and the biomarkers confirmed the robustness of these observations. Other markers of inflammation did not differ by anemia status.

Studies have demonstrated that anemia in CKD patients is an independent risk factor for CVD events and mortality. Walker et al. [12] found that patients with anemia (defined as $\mathrm{Hgb}<120 \mathrm{~g} / \mathrm{l}$ ) had a fivefold increase in hospitalization for myocardial infarction. Another study found a threefold higher risk of CVD in anemic patients (defined as $\mathrm{Hgb}<130 \mathrm{~g} / \mathrm{l}$ for men and $<120 \mathrm{~g} / \mathrm{l}$ for women) regardless of the degree of renal impairment [9]. In the present study, most of the traditional risk factors did not differ between anemic and non-anemic patients, namely gender, etiology of CKD, ferritin, LDL cholesterol or smoking status. In contrast, endothelial activation markers were elevated in anemic patients.

Fibrinogen, an acute-phase reactant and marker of endothelial activation [20-22], is an independent risk factor for CVD disease, left ventricular hypertrophy and mortality in patients without kidney disease $[12,22,23]$. Recently, it has been associated with cardiovascular morbidity, left ventricular hypertrophy and clotting of the vascular access in hemodialysis patients $[6,23,24]$. In our study, the fibrinogen levels in anemic patients were comparable to the high-risk general population for CVD [25] but lower than those found in hemodialysis patients at risk of CVD [26]. Age influences the fibrinogen level [27]. Thus, we adjusted for age in a multivariate model. Furthermore, there was no difference between groups in the known factors that may influence fibrinogen levels - gender, smoking status, and low-density lipoprotein cholesterol, and proteinuria status. Molecular mechanisms underlying the pathogenic role of fibrinogen are still being uncovered. Integrin-dependent signal transduction pathway leading to induction to chemotactic activity by fibrinogen may contribute to induction of chemokines in early atherosclerosis. Fibrinogen also increases monocyte chemoattracting protein-1, platelet-derived growth factor and interleukin-8 [22]. Thus, fibrinogen may activate various pathways implicated in CVD pathogenesis.

In our study, we found higher vWF levels in a high-risk population not previously reported. vWF, a glycoprotein secreted by endothelial cells, has been shown to be involved in platelet aggregation and adhesion [28]. An animal model showed that inactivation of vWF resulted in stopping endothelial cell activation and delayed formation of fatty streaks [29]. vWF is a weak predictor of CVD events in the general population, but it strongly predicts
CVD events and mortality in high-risk patients (e.g. diabetes, vascular disease). The significance persisted after adjusting for multiple risk factors including CRP levels $[17,30]$. Since blood group type may influence vWF levels [31], we looked at the prevalence of blood group A by anemia status. We did not find any difference between the 2 groups. In summary, vWF may play an important role in CVD events in ND-CKD patients.

In our study, VCAM-1 was significantly elevated in anemic as opposed to non-anemic patients. VCAM-1, an endothelial activator and mediator of lymphocyte adhesion and migration, has also been associated with adverse CVD events [32-35]. The mechanism of endothelial cell activation by VCAM-1 may be by generating reactive oxygen species via NADPH oxidase, activation of matrix metalloproteinase and cross-talk with very-late antigen 4 [35-38]. In a diabetic population, VCAM-1 along with other adhesion molecules predicted the development of macrovascular disease [39]. Another study reported that elevated VCAM-1 levels were associated with CVD events in a hemodialysis population [26]. Thus, VCAM-1 may also play an important role in CVD events in ND-CKD patients.

Our study had several strengths and limitations. The major limitation was that baseline covariates might have confounded the association between anemia and the markers of endothelial activation. Although both groups were similar at baseline, sample size was small. We also excluded patients who were hospitalized or had history of infection in the past 30 days. We did not include patients on dialysis as the dialysis membrane may itself activate inflammatory and endothelial activation markers [26, $40-42]$. The assays were performed using defined validated techniques with limited intra-assay variability. Although we performed sensitivity analyses of anemia and biomarkers thereby increasing the robustness of the study, we believe that this study is hypothesis generating.

In conclusion, we report an association between anemia and increased levels of fibrinogen, vWF and VCAM1 in ND-CKD patients. Elevated levels of these endothelial markers may be germane to define heightened CVD risk among anemic CKD patients. Prospective studies are needed to confirm these findings. 


\section{Acknowledgements}

We thank Timothy Pelura, PhD, David Hesson, PhD, Mark Lupher Jr., PhD, and Lynne Murray, PhD, of Promedior Inc. for their support for this study.

Dr. Patel was supported by T32-DK007527-23. The study was funded in part by Promedior Inc., Malvern, Pa., USA.

\section{Conflict-of-Interest Disclosure}

Dr. Singh reports receiving consulting fees from Ortho Biotech Clinical Affairs/Johnson \& Johnson, Amgen, Roche, Merck, Abbott, Watson, and lecture fees from Ortho Biotech Clinical Affairs/Johnson \& Johnson, Roche, Amgen, Abbott, Watson, and Genzyme; serving on advisory boards for Ortho Biotech Clinical Affairs, Roche, Watson, AMAG Inc., and Amgen, and receiving grant support from Ortho Biotech Clinical Affairs, Dialysis Clinic Inc., Roche, Baxter, Johnson \& Johnson, Amgen, and Watson. Dr. Singh is a Medical Director of Dialysis Clinics Inc.

\section{References}

-1 Schiffrin EL, Lipman ML, Mann JF: Chronic kidney disease: effects on the cardiovascular system. Circulation 2007;116:85-97.

$\checkmark 2$ Ridker PM, Brown NJ, Vaughan DE, Harrison DG, Mehta JL: Established and emerging plasma biomarkers in the prediction of first atherothrombotic events. Circulation 2004; 109:IV6-IV19.

-3 Oberg BP, McMenamin E, Lucas FL, McMonagle E, Morrow J, Ikizler TA, Himmelfarb J: Increased prevalence of oxidant stress and inflammation in patients with moderate to severe chronic kidney disease. Kidney Int 2004;65:1009-1016.

4 Descamps-Latscha B, Witko-Sarsat V, Nguyen-Khoa T, Nguyen AT, Gausson V, Mothu N, London GM, Jungers P: Advanced oxidation protein products as risk factors for atherosclerotic cardiovascular events in nondiabetic predialysis patients. Am J Kidney Dis 2005;45:39-47.

5 Hjerkinn EM, Seljeflot I, Sandvik L, Hjermann I, Arnesen H: Markers of endothelial cell activation in elderly men at high risk for coronary heart disease. Scand J Clin Lab Invest 2005;65:201-209.

6 Kirmizis D, Tsiandoulas A, Pangalou M, Koutoupa E, Rozi P, Protopappa M, Barboutis K: Validity of plasma fibrinogen, d-dimer, and the von Willebrand factor as markers of cardiovascular morbidity in patients on chronic hemodialysis. Med Sci Monit 2006; 12:CR55-CR62.

7 Knight EL, Rimm EB, Pai JK, Rexrode KM, Cannuscio CC, Manson JE, Stampfer MJ, Curhan GC: Kidney dysfunction, inflammation, and coronary events: a prospective study. J Am Soc Nephrol 2004;15:18971903.

8 Li Vecchi M, Fuiano G, Francesco M, Mancuso D, Faga T, Sponton A, Provenzano R, Andreucci M, Tozzo C: Prevalence and severity of anaemia in patients with type 2 diabetic nephropathy and different degrees of chronic renal insufficiency. Nephron Clin Pract 2007;105:c62-c67.

-9 Jurkovitz CT, Abramson JL, Vaccarino LV, Weintraub WS, McClellan WM: Association of high serum creatinine and anemia increases the risk of coronary events: results from the prospective community-based atherosclerosis risk in communities (ARIC) study. J Am Soc Nephrol 2003;14:2919-2925.

10 Vlagopoulos PT, Tighiouart H, Weiner DE, Griffith J, Pettitt D, Salem DN, Levey AS, Sarnak MJ: Anemia as a risk factor for cardiovascular disease and all-cause mortality in diabetes: the impact of chronic kidney disease. J Am Soc Nephrol 2005;16:3403-3410.

11 Weiner DE, Tighiouart H, Vlagopoulos PT, Griffith JL, Salem DN, Levey AS, Sarnak MJ: Effects of anemia and left ventricular hypertrophy on cardiovascular disease in patients with chronic kidney disease. J Am Soc Nephrol 2005; 16:1803-1810.

12 Walker AM, Schneider G, Yeaw J, Nordstrom B, Robbins S, Pettitt D: Anemia as a predictor of cardiovascular events in patients with elevated serum creatinine. J Am Soc Nephrol 2006;17:2293-2298.

13 Racki S, Zaputovic L, Mavric Z, Vujicic B, Dvornik S: C-reactive protein is a strong predictor of mortality in hemodialysis patients. Ren Fail 2006;28:427-433.

-14 Honda $\mathrm{H}$, Qureshi AR, Heimburger O, Barany P, Wang K, Pecoits-Filho R, Stenvinkel P, Lindholm B: Serum albumin, C-reactive protein, interleukin 6 , and fetuin a as predictors of malnutrition, cardiovascular disease, and mortality in patients with ESRD. Am J Kidney Dis 2006;47:139-148.

15 Menon V, Greene T, Wang X, Pereira AA, Marcovina SM, Beck GJ, Kusek JW, Collins AJ, Levey AS, Sarnak MJ: C-reactive protein and albumin as predictors of all-cause and cardiovascular mortality in chronic kidney disease. Kidney Int 2005;68:766-772.

16 Vischer UM: Von Willebrand factor, endothelial dysfunction, and cardiovascular disease. J Thromb Haemost 2006;4:1186-1193.

17 Jager A, van Hinsbergh VW, Kostense PJ, Emeis JJ, Yudkin JS, Nijpels G, Dekker JM, Heine RJ, Bouter LM, Stehouwer CD: Von Willebrand factor, C-reactive protein, and 5 year mortality in diabetic and nondiabetic subjects: the Hoorn study. Arterioscler Thromb Vasc Biol 1999;19:3071-3078.

18 Danesh J, Lewington S, Thompson SG, Lowe GD, Collins R, Kostis JB, Wilson AC, Folsom AR, Wu K, Benderly M, Goldbourt U, Willeit
J, Kiechl S, Yarnell JW, Sweetnam PM, Elwood PC, Cushman M, Psaty BM, Tracy RP, Tybjaerg-Hansen A, Haverkate F, de Maat MP, Fowkes FG, Lee AJ, Smith FB, Salomaa V, Harald K, Rasi R, Vahtera E, Jousilahti P, Pekkanen J, D’Agostino R, Kannel WB, Wilson PW, Tofler G, Arocha-Pinango CL, Rodriguez-Larralde A, Nagy E, Mijares M, Espinosa R, Rodriquez-Roa E, Ryder E, DiezEwald MP, Campos G, Fernandez V, Torres E, Marchioli R, Valagussa F, Rosengren A, Wilhelmsen L, Lappas G, Eriksson H, Cremer P, Nagel D, Curb JD, Rodriguez B, Yano K, Salonen JT, Nyyssonen K, Tuomainen TP, Hedblad B, Lind P, Loewel H, Koenig W, Meade TW, Cooper JA, De Stavola B, Knottenbelt C, Miller GJ, Bauer KA, Rosenberg RD, Sato S, Kitamura A, Naito Y, Palosuo T, Ducimetiere P, Amouyel P, Arveiler D, Evans AE, Ferrieres J, Juhan-Vague I, Bingham A, Schulte H, Assmann G, Cantin B, Lamarche B, Despres JP, Dagenais GR, Tunstall-Pedoe $\mathrm{H}$, Woodward M, Ben-Shlomo Y, Davey Smith G, Palmieri V, Yeh JL, Rudnicka A, Ridker P, Rodeghiero F, Tosetto A, Shepherd J, Ford I, Robertson M, Brunner E, Shipley M, Feskens EJ, Kromhout D, Dickinson A, Ireland B, Juzwishin K, Kaptoge S, Memon A, Sarwar N, Walker M, Wheeler J, White I, Wood A: Plasma fibrinogen level and the risk of major cardiovascular diseases and nonvascular mortality: an individual participant meta-analysis. JAMA 2005;294:1799_ 1809.

19 Levey AS, Bosch JP, Lewis JB, Greene T, Rogers N, Roth D: A more accurate method to estimate glomerular filtration rate from serum creatinine: a new prediction equation. Modification of diet in renal disease study group. Ann Intern Med 1999;130:461-470.

20 Tyagi N, Roberts AM, Dean WL, Tyagi SC, Lominadze D: Fibrinogen induces endothelial cell permeability. Mol Cell Biochem 2008;307:13-22.

21 Bosevski M, Borozanov V, Peovska I, Georgievska-Ismail L: Endothelial dysfunction correlates with plasma fibrinogen and HDL cholesterol in type 2 diabetic patients with coronary artery disease. Bratisl Lek Listy 2007;108:297-300. 
-22 Seeger FH, Blessing E, Gu L, Bornhold R, Denger S, Kreuzer J: Fibrinogen induces chemotactic activity in endothelial cells. Acta Physiol Scand 2002;176:109-115.

-23 Zoccali C, Mallamaci F, Tripepi G, Cutrupi S, Parlongo S, Malatino LS, Bonanno G, Rapisarda F, Fatuzzo P, Seminara G, Stancanelli B, Nicocia G, Buemi M: Fibrinogen, mortality and incident cardiovascular complications in end-stage renal failure. J Intern Med 2003;254:132-139.

-24 Song IS, Yang WS, Kim SB, Lee JH, Kwon TW, Park JS: Association of plasma fibrinogen concentration with vascular access failure in hemodialysis patients. Nephrol Dial Transplant 1999;14:137-141.

-25 Acevedo M, Pearce GL, Kottke-Marchant K, Sprecher DL: Elevated fibrinogen and homocysteine levels enhance the risk of mortality in patients from a high-risk preventive cardiology clinic. Arterioscler Thromb Vasc Biol 2002;22:1042-1045.

-26 Papayianni A, Alexopoulos E, Giamalis P, Gionanlis L, Belechri AM, Koukoudis P, Memmos D: Circulating levels of ICAM-1, VCAM-1, and MCP-1 are increased in haemodialysis patients: association with inflammation, dyslipidaemia, and vascular events. Nephrol Dial Transplant 2002;17: 435-441.

-27 Drenos F, Miller GJ, Humphries SE: Increase of plasma fibrinogen levels and variability with age in a sample of middle aged healthy men. Ann Hum Genet 2007;71:43-53.

-28 Massberg S, Brand K, Gruner S, Page S, Muller E, Muller I, Bergmeier W, Richter T, Lorenz M, Konrad I, Nieswandt B, Gawaz M: A critical role of platelet adhesion in the initiation of atherosclerotic lesion formation. J Exp Med 2002;196:887-896.
29 Methia N, Andre P, Denis CV, Economopoulos M, Wagner DD: Localized reduction of atherosclerosis in von Willebrand factor-deficient mice. Blood 2001;98:1424-1428.

30 Folsom AR, Wu KK, Rosamond WD, Sharrett AR, Chambless LE: Prospective study of hemostatic factors and incidence of coronary heart disease: the atherosclerosis risk in communities (ARIC) study. Circulation 1997;96:1102-1108.

-31 Castaman G, Eikenboom JC: ABO blood group also influences the von Willebrand factor (VWF) antigen level in heterozygous carriers of VWF null alleles, type $2 \mathrm{~N}$ mutation Arg854GIn, and the missense mutation Cys2362Phe. Blood 2002;100:1927-1928.

32 Jude EB, Douglas JT, Anderson SG, Young MJ, Boulton AJ: Circulating cellular adhesion molecules ICAM-1, VCAM-1, P- and Eselectin in the prediction of cardiovascular disease in diabetes mellitus. Eur J Intern Med 2002;13:185-189.

33 Demerath E, Towne B, Blangero J, Siervogel RM: The relationship of soluble ICAM-1, VCAM-1, P-selectin and E-selectin to cardiovascular disease risk factors in healthy men and women. Ann Hum Biol 2001;28: 664-678.

34 Andresen TK, Svennevig JL, Videm V: Soluble VCAM-1 is a very early marker of endothelial cell activation in cardiopulmonary bypass. Perfusion 2002;17:15-21.

35 Deem TL, Abdala-Valencia H, Cook-Mills JM: VCAM-1 activation of endothelial cell protein tyrosine phosphatase 1B. J Immunol 2007;178:3865-3873.
36 Abdala-Valencia H, Cook-Mills JM: VCAM1 signals activate endothelial cell protein kinase Calpha via oxidation. J Immunol 2006; 177:6379-6387.

37 Papayannopoulou T, Priestley GV, Nakamoto B: Anti-VLA4/VCAM-1-induced mobilization requires cooperative signaling through the kit/mkit ligand pathway. Blood 1998;91:2231-2239.

>38 Deem TL, Cook-Mills JM: Vascular cell adhesion molecule 1 (VCAM-1) activation of endothelial cell matrix metalloproteinases: role of reactive oxygen species. Blood 2004; 104:2385-2393.

>39 Mrowka C, Sieberth HG: Detection of circulating adhesion molecules ICAM-1, VCAM1 and E-selectin in Wegener's granulomatosis, systemic lupus erythematosus and chronic renal failure. Clin Nephrol 1995;43: 288-296.

40 Korantzopoulos P, Siogas K, Galaris D: The association of oxidative stress and inflammation in hemodialysis patients. Am J Kidney Dis 2004;43:192.

41 Costa E, Lima M, Alves JM, Rocha S, RochaPereira P, Castro E, Miranda V, Faria MD, Loureiro A, Quintanilha A, Belo L, SantosSilva A: Inflammation, T-cell phenotype, and inflammatory cytokines in chronic kidney disease patients under hemodialysis and its relationship to resistance to recombinant human erythropoietin therapy. J Clin Immunol 2008;28:268-275.

42 Wanner C, Bahner U, Mattern R, Lang D, Passlick-Deetjen J: Effect of dialysis flux and membrane material on dyslipidaemia and inflammation in haemodialysis patients. Nephrol Dial Transplant 2004;19:25702575 . 